\title{
Nutritional Status of School Going Children (7-9 years) on the Basis of Food Habit in Rural area of Kanpur Dehat District (Uttar Pradesh)
}

\author{
Anoop Kumar ${ }^{1 *}$ and Pinki Khanna ${ }^{2}$ \\ ${ }^{1}$ Department of Food and Nutrition, Dr. B.R. Ambedkar University of Social Sciences, Dr. \\ Ambedkar Nagar Mhow Indore, Madhya Pradesh, India \\ ${ }^{2}$ Department of Home science and Hospitality Management, PSSCIVE, Bhopal, Madhya \\ Pradesh, India \\ *Corresponding author
}

\section{A B S T R A C T}

\section{Keywords}

Nutritional assessment, Dietary intake, School going children, Food habits, Food intake

Article Info

Accepted: 10 May 2021 Available Online: 10 June 2021
School age period is a critical period of growth and development. In this period the activities, diet and nutrition of children influence their physical and cognitive development. The present study aimed to assess the nutritional status of school going children of 7-9 years old children on the basis of their food habits. The study was conducted among the government primary schools of rural areas of Kanpur Dehat, Uttar Pradesh. The data was collected by the pre-design oral questionnaires. The dietary assessment was done which include 24 hour recall method and their food habits. The data was analyzed with appropriate statistics. Results of the study found that majority of children were belonged from the lower economic group and SC category. The majority of students were found nonvegetarian. The diets of the school age children were found low in functional foods like green leafy vegetables, fruits, milk and protein foods. Their diet was found mostly dependent cereals and pulses. They were found dependent on the Mid-Day Meal for school lunch and the habit of skipping meals was found common among the studied population of 7-9 years of age. Their socioeconomic status was found related with their diet quality.

\section{Introduction}

Nutritional status is the condition of health of the individual as influenced by the utilization of the nutrient. It can be determined only by the correlation of the information obtained through a careful medication and diet history, a thorough physical examination, and appropriate laboratory tests. Nutritional assessment is a detailed investigation to identify and quantify specific nutritional problems (Bond, 1997). Assessment of nutritional status is essential for early detection of the degree of malnutrition in the 
risk population in the community. It can be accomplished by following four methods-

Anthropometric

Biochemical

Clinical

Dietary

Individual Dietary Habits affects the nutritional status

\section{Food habits}

Food habits are the most deeply entrenched aspects of any culture they have deep psychological roots and are associated with love, affection, self-esteem, self-image and social prestige.

The family of school going children plays an important role to shaping the food habits and they pass to one generation to another.

\section{Food faddism}

In the selection of food personal likes and dislikes, interest and believes are called food fads. And this can be found in the school age children. The food fads may stand in the way of correcting nutritional deficiency.

\section{Dietary intake}

The amount and portion size of the food should be in good proportion to meet the needs of daily calories and nutrients. This is another factor which may affect the nutritional status of a child.

\section{Food Adequacy}

The food should contain a good amount of nutrients. It should fulfill the adequate percent of daily requirement of each nutrient in the diet of school going children.

\section{Materials and Methods}

The study was conducted in Kanpur Dehat district of Uttar Pradesh district have been selected purposively. Four blocks are taken under consideration for the study from the 10 blocks of Kanpur Dehat district will be selected randomly for the study. Five schools are selected from each block for the study. Therefore, 13 samples will be selected from each school.

A total 260 rural school children will be selected through simple random sampling from the selected rural schools. 13 children belonging to the age group, 7-9 years are taken under consideration for the study in every school. 260 samples were selected for the study purpose from rural areas school children. This was selected from different schools through simple random sampling. The socio-demographic profile of the subject was collected with the help of pre-tested questionnaire which included the dietary assessment methods.

\section{Results and Discussion}

\section{Food Habit}

On the study of the data given in the table no. 1 it was found that $54.6 \%$ children were nonvegetarian with $35 \%$ boy and $19.6 \%$ girl respondents. Whereas, $45.4 \%$ children were belong to vegetarian category with $33 \%$ girls and $12.3 \%$ boy respondents.

In the present study it was analyzed that the majority of rural school age children in the selected study area were taking non-vegetarian diets including egg, meat, fish and chicken which are the good sources of animal based protein in the diet. 


\section{Number of meals per day}

Table no. 2 found that $72.3 \%$ children $(36.2 \%$ boys and $36.2 \%$ girls) were taking three meals per day. $15.4 \%$ children were taking four meals per day which includes $9.6 \%$ girls and $5.8 \%$ boys. About $12.3 \%$ children were taking only two meals per day with higher percent of girls $6.9 \%$ than boys $5.4 \%$.The diet related data was recorded under four meal patterns as breakfast, lunch, evening tea time and dinner. But the recorded data found that the majority of children of 7-9 years were taking only three meals per day including breakfast, lunch and dinner. The habit of skipping meals was found common among children. It is very important for the children of school age to take their breakfast before going to school which create good focus and better brain development. Evening tea time meal was skipped by most of the children due to lack of food, time, hunger, less tasty food, hurry to play and money to prepare or purchase any snacks to eat.

\section{Additional Food Intake}

Table no. 3 shows that $66.2 \%$ children $(32.3 \%$ boys and $33.8 \%$ girls) preferred puffed cereals as additional food. Whereas, the rest $33.8 \%$ children prefer to take fruits as additional food item in their diet in which girls respondents leads the boys with $18.8 \%$ and $15 \%$ respectively.

Additional food items should be included in the diet of school age children as the daily staple food diet may become very monotonous for the children.

Additional foods like healthy snacks, fruits and drinks contribute in as a small percentage in the daily calorie needs. In the present study it was found that majority of children were like to eat fruits as additional food in the diet rather than puffed cereals or any other product.

\section{Consumption of sweets}

Table no. 4 shows that that majority of children $40.4 \%$ were taking sweets daily in their diet in which $23.8 \%$ were girls and $16.5 \%$ were boy respondents. The children who were taking sweets on weekly basis were around $7.7 \%$ (4.6\% were boys and 3.1 were girls). The majority of children $51.9 \%$ were taking sweets sometimes according to the availability, in which $26.2 \%$ were boys and $25.8 \%$ were girls. Excess sweet consumption may cause dental problems in school age children. The study record data related with sweet consumption and found that 135 children out of 260 were like to prefer eat sweet items sometimes in a month followed by daily and weekly consumption among rural school age children. The study also concluded that the girls would like to eat sweets daily in their diet as compare to boys.

\section{Water Intake}

Table no. 5 shows that majority group with $82.3 \%$ respondents ( $42.3 \%$ boys and 405 girls) were drinking three glasses of water per day. Similarly, $13.5 \%$ children who involve $10 \%$ girls and only $3 \%$ boys were drinking two glasses of water which is not sufficient for them. Among the 260 children, only $4.2 \%$ ( $2.7 \%$ girls and $1.5 \%$ boys) were taking five glasses of water per day. No one was taking eight glasses of water per day. Adequate water intake prevents constipation and dehydration in school age children. The study found that the majority of children of 7-9 year were taking three glasses of water per day followed by two and five glasses of water.

\section{Consumption of milk}

Table no. 6 shows that the children were including milk in their diets. Majority of children with $71.2 \%$ (36.5\% girls and $34.6 \%$ boys) were taking milk sometimes in their 
diets whereas, $27.7 \%$ children were taking milk daily in which girls leads with $15.8 \%$ than boys with $11.9 \%$. Only $1.2 \%$ children ( 0.85 boys and $0.4 \%$ girls) were never taking milk in their diets. Milk intake is important to fulfill the calcium requirements among school age children. Generally, the school age children tend to avoid milk completely from their diet and they start basic diet only after pre-school age. But it is important to continue milk feeding as later as possible to ensure good bone mineral density among children. Children require of 6-12 years required 600 $\mathrm{mg}$ of calcium per day which was fulfilled by 2-3 glasses of milk per day. The study found that the majority of children were found irregular to drink milk and only $27.7 \%$ children were taking milk daily in their diet.

\section{Habit of drinking water between the meals of after the meal}

Table no. 7 shows that $97.3 \%$ children were not taking water between the meals, whereas, only $2.7 \%$ children with $1.9 \%$ girls respondents and $0.8 \%$ boys respondents were taking water between meals. Water taken between the meals and after the meals impart opposite effects on the food consumption and satiety level. Water helps to digest food when taken after 20-30 minutes of food intake whereas drinking water between the meals interrupts in the digestion of the food. The present analysed this food habit and found that majority of children were not practising these kinds of habit.

\section{Skipping meal pattern}

Table no. 8 shows that $51.9 \%$ children was not skipping any meal in a day. Whereas, $37.3 \%$ children were skipping their meal due to lack of appetite, $6.5 \%$ (3.8\% girls and $2.7 \%$ boys) were skipping due to lack of time and $4.2 \%$ (3.1\% girls and $1.2 \%$ boys) were skipping meals due to not being tasty. On statistical analysis it was found that the chi square value (1.662) was found non-significant at 5\% level of significance. Hence, it can be concluded that the nature of the children of skipping meals in a day was not depend upon their gender as it was non-associative.

The study found that the majority of children about $52 \%$ were not skipping the daily meals which they were provided by the mother and school. But the rest were skipping the meals in a day under the given reason in which maximum children skip the meal due to lack of appetite followed by lack of time and less tasty food. The most skipped meals by the children of school age were breakfast and evening snacks. A study conducted by NIN (2003-2004) confirmed that eating breakfast regularly is a significant factor influencing better academic performance. The meal taken on return from school is important to meet the nutritional requirements.

\section{Supplement intake}

(Table no.9) the assessment found that $88.1 \%$ children were not taking any supplements in their diet. Only 11.95 children were taking supplements in their diet. It was found that about $6.5 \%$ in which $3.5 \%$ were females taking commercial supplements. And 5.4\% children were taking homemade supplements with the same extent in girls and boys.

\section{Snacking Habits}

(Table no.10) it was found that $85 \%$ children were not involved in snacking. The rest $15 \%$ children were take snacks between the meals in which $8.5 \%$ were girls and $6.5 \%$ were boy respondents. Healthy home-made snacks can be incorporated in the regular diet to make it more interesting and nutritious. The study found that only $15 \%$ children were had the habit of snacking in which girls were leading the boys. 
Table.1 Distribution of respondents according to Food Habit

\begin{tabular}{|c|c|c|c|c|c|c|}
\hline \multirow{2}{*}{ Dietary Pattern } & \multicolumn{2}{|c|}{ Boys } & \multicolumn{2}{c|}{ Girls } & \multicolumn{2}{c|}{ Total } \\
\cline { 2 - 7 } & $\mathrm{F}$ & $\%$ & $\mathrm{~F}$ & $\%$ & $\mathrm{~F}$ & $\%$ \\
\hline Vegetarian & 32 & 12.3 & 86 & 33.1 & 118 & 45.4 \\
\hline Non-vegetarian & 91 & 35.0 & 51 & 19.6 & 142 & 54.6 \\
\hline Total & 123 & 47.3 & 137 & 52.7 & 260 & 100.0 \\
\hline$\chi^{2}$ & \multicolumn{3}{|c|}{$35.328 * *$} & \multicolumn{2}{c|}{$\mathrm{P}<0.01$} \\
\hline
\end{tabular}

Table.2 Distribution of respondents according to meals taken per day

\begin{tabular}{|c|c|c|c|c|c|c|}
\hline \multirow{2}{*}{$\begin{array}{c}\text { No. of Meals take in a } \\
\text { day }\end{array}$} & \multicolumn{3}{|c|}{ Boys } & \multicolumn{2}{c|}{ Girls } & \multicolumn{2}{c|}{ Total } \\
\cline { 2 - 7 } Two & F & $\%$ & F & $\%$ & F & $\%$ \\
\hline Three & 14 & 5.4 & 18 & 6.9 & 32 & 12.3 \\
\hline Four & 94 & 36.2 & 94 & 36.2 & 188 & 72.3 \\
\hline Total & 15 & 5.8 & 25 & 9.6 & 40 & 15.4 \\
\hline$\chi^{2}$ & 123 & 47.3 & 137 & 52.7 & 260 & 100.0 \\
\hline
\end{tabular}

Table.3 Distribution of respondents according to additional food intake

\begin{tabular}{|c|c|c|c|c|c|c|}
\hline Additional food intake & \multicolumn{2}{|c|}{ Boys } & \multicolumn{2}{c|}{ Girls } & \multicolumn{2}{c|}{ Total } \\
\cline { 2 - 7 } & $\mathrm{F}$ & $\%$ & $\mathrm{~F}$ & $\%$ & $\mathrm{~F}$ & $\%$ \\
\hline Fruit & 84 & 32.3 & 88 & 33.8 & 172 & 66.2 \\
\hline Puffed cereals & 39 & 15.0 & 49 & 18.8 & 88 & 33.8 \\
\hline Total & 123 & 47.3 & 137 & 52.7 & 260 & 100.0 \\
\hline$\chi^{2}$ & \multicolumn{6}{|c|}{0.477} \\
\hline
\end{tabular}

Table.4 Distribution of respondents according to consumption of sweet item

\begin{tabular}{|c|c|c|c|c|c|c|}
\hline Prefer any sweet item in & \multicolumn{2}{|c|}{ Boys } & \multicolumn{2}{c|}{ Girls } & \multicolumn{2}{c|}{ Total } \\
\cline { 2 - 7 } diet & F & $\%$ & F & $\%$ & F & $\%$ \\
\hline Daily & 43 & 16.5 & 62 & 23.8 & 105 & 40.4 \\
\hline Weekly & 12 & 4.6 & 8 & 3.1 & 20 & 7.7 \\
\hline Sometime & 68 & 26.2 & 67 & 25.8 & 135 & 51.9 \\
\hline Total & 123 & 47.3 & 137 & 52.7 & 260 & 100.0 \\
\hline$\chi^{2}$ & \multicolumn{4}{|c|}{3.502} & \multicolumn{2}{c|}{$\mathrm{p}>0.05$} \\
\hline
\end{tabular}


Table.5 Distribution of respondents according to daily water intake

\begin{tabular}{|c|c|c|c|c|c|c|}
\hline \multirow{2}{*}{$\begin{array}{c}\text { How many glasses of } \\
\text { water } \\
\text { drink in a day }\end{array}$} & \multicolumn{2}{|c|}{ Boys } & \multicolumn{2}{c|}{ Girls } & \multicolumn{2}{c|}{ Total } \\
\cline { 2 - 7 } & $\mathrm{F}$ & $\%$ & $\mathrm{~F}$ & $\%$ & $\mathrm{~F}$ & $\%$ \\
\hline Two & 9 & 3.5 & 26 & 10.0 & 35 & 13.5 \\
\hline Three & 110 & 42.3 & 104 & 40.0 & 214 & 82.3 \\
\hline Five & 4 & 1.5 & 7 & 2.7 & 11 & 4.2 \\
\hline Eight & - & - & - & - & - & 0.0 \\
\hline Total & 123 & 47.3 & 137 & 52.7 & 260 & 100.0 \\
\hline$\chi^{\mathbf{2}}$ & \multicolumn{2}{|c|}{$7.565^{*}$} & & \multicolumn{2}{c|}{$\mathrm{P}<0.05$} \\
\hline
\end{tabular}

Table.6 Distribution of respondents according to milk intake

\begin{tabular}{|c|c|c|c|c|c|c|}
\hline \multirow{2}{*}{$\begin{array}{c}\text { Frequency of milk } \\
\text { intake }\end{array}$} & \multicolumn{2}{|c|}{ Boys } & \multicolumn{2}{c|}{ Girls } & \multicolumn{2}{c|}{ Total } \\
\cline { 2 - 7 } & $\mathrm{F}$ & $\%$ & $\mathrm{~F}$ & $\%$ & $\mathrm{~F}$ & $\%$ \\
\hline Daily & 31 & 11.9 & 41 & 15.8 & 72 & 27.7 \\
\hline Sometimes & 90 & 34.6 & 95 & 36.5 & 185 & 71.2 \\
\hline Never & 2 & 0.8 & 1 & 0.4 & 3 & 1.2 \\
\hline Total & 123 & 47.3 & 137 & 52.7 & 260 & 100.0 \\
\hline $\boldsymbol{\chi}^{\mathbf{2}}$ & \multicolumn{4}{|c|}{0.722} & \multicolumn{2}{c|}{$\mathrm{p}>0.05$} \\
\hline
\end{tabular}

Table.7 Distribution of respondents according to the habit of drink water in between meals or after meal

\begin{tabular}{|c|c|c|c|c|c|c|}
\hline $\begin{array}{c}\text { Drink water in } \\
\text { between meals } \\
\text { or after meal }\end{array}$ & \multicolumn{2}{|c|}{ Boys } & \multicolumn{2}{c|}{ Girls } & \multicolumn{2}{c|}{ Total } \\
\hline Yes & 2 & 0.8 & F & $\%$ & F & $\%$ \\
\hline No & 121 & 46.5 & 132 & 1.9 & 7 & 2.7 \\
\hline Total & 123 & 47.3 & 137 & 52.7 & 253 & 97.3 \\
\hline$\chi^{2}$ & \multicolumn{2}{|c|}{1.390} & \multicolumn{2}{c|}{$\mathrm{p}>0.05$} \\
\hline
\end{tabular}

Table.8 Distribution of respondents according to the nature of skipping meals per day

\begin{tabular}{|c|c|c|c|c|c|c|}
\hline $\begin{array}{c}\text { Skip meal in a day } \\
\text { and why? }\end{array}$ & \multicolumn{2}{|c|}{ Boys } & \multicolumn{2}{c|}{ Girls } & \multicolumn{2}{c|}{ Total } \\
\hline Yes & F & $\%$ & F & $\%$ & F & $\%$ \\
\hline No & - & - & - & - & - & - \\
\hline Lack of time & 7 & 26.5 & 66 & 25.4 & 135 & 51.9 \\
\hline Lack of appetite & 44 & 2.7 & 10 & 3.8 & 17 & 6.5 \\
\hline No tasty & 3 & 16.9 & 53 & 20.4 & 97 & 37.3 \\
\hline Total & 123 & 47.3 & 8 & 3.1 & 11 & 4.2 \\
\hline$\chi^{2}$ & \multicolumn{2}{|c|}{1.662} & 52.7 & 260 & 100.0 \\
\hline
\end{tabular}


Table.9 Distribution of respondents according to supplement food intake

\begin{tabular}{|c|c|c|c|c|c|c|}
\hline Take any food supplements & \multicolumn{2}{|c|}{ Boys } & \multicolumn{2}{c|}{ Girls } & \multicolumn{2}{c|}{ Total } \\
\cline { 2 - 8 } & $\mathrm{F}$ & $\%$ & $\mathrm{~F}$ & $\%$ & $\mathrm{~F}$ & $\%$ \\
\hline Yes & - & - & - & - & - & - \\
\hline No & 108 & 41.5 & 121 & 46.5 & 229 & 88.1 \\
\hline $\begin{array}{c}\text { Commercial supplements } \\
\text { (Complain, Horlicks and } \\
\text { Boost etc.) }\end{array}$ & 8 & 3.1 & 9 & 3.5 & 17 & 6.5 \\
\hline $\begin{array}{c}\text { Homemade supplements } \\
\text { (Kanji, Oats, Porridge) }\end{array}$ & 7 & 2.7 & 7 & 2.7 & 14 & 5.4 \\
\hline Total & 123 & 47.3 & 137 & 52.7 & 260 & 100.0 \\
\hline$\chi^{2}$ & \multicolumn{2}{|c|}{0.043} & & \multicolumn{2}{c|}{$\mathrm{p}>0.05$} \\
\hline
\end{tabular}

Table.10 Distribution of respondents according to their snacking habits

\begin{tabular}{|c|c|c|c|c|c|c|}
\hline Snacking habit & \multicolumn{2}{|c|}{ Boys } & \multicolumn{2}{c|}{ Girls } & \multicolumn{2}{c|}{ Total } \\
\cline { 2 - 7 } & F & $\%$ & F & $\%$ & F & $\%$ \\
\hline Yes & 17 & 6.5 & 22 & 8.5 & 39 & 15.0 \\
\hline No & 106 & 40.8 & 115 & 44.2 & 221 & 85.0 \\
\hline Total & 123 & 47.3 & 137 & 52.7 & 260 & 100.0 \\
\hline$\chi^{2}$ & \multicolumn{6}{|c|}{0.254} \\
\hline
\end{tabular}

Table.11 Distribution of respondents according to their alternative for the lunch box

\begin{tabular}{|c|c|c|c|c|c|c|}
\hline $\begin{array}{c}\text { Alternative for } \\
\text { lunch box }\end{array}$ & \multicolumn{2}{|c|}{ Boys } & \multicolumn{2}{c|}{ Girls } & \multicolumn{2}{c|}{ Total } \\
\hline Eat at canteen & F & $\%$ & F & $\%$ & F & $\%$ \\
\hline Go to home & 18 & 6.9 & 25 & 9.6 & 43 & 16.5 \\
\hline Skip lunch & 2 & 0.8 & 1 & 0.4 & 3 & 1.2 \\
\hline Mid-day meal & 103 & 39.6 & 111 & 42.7 & 214 & 82.3 \\
\hline Total & 123 & 47.3 & 137 & 52.7 & 260 & 100.0 \\
\hline$\chi^{2}$ & \multicolumn{2}{|c|}{0.329} & & \multicolumn{2}{c|}{$\mathrm{p}>0.05$} \\
\hline
\end{tabular}

\section{Alternative for lunch}

(Table no.11) the study shows that $82.3 \%$ children $(42.7 \%$ girl and $39.6 \%$ boys) were depending upon the mid-day meal provided by the school if they don't carry the lunch box. About $16.5 \%$ children were go back to home if they don't carry the lunch box whereas, $1.2 \%$ (boys $0.8 \%$ and girl $0.4 \%$ ) children choose to skip lunch. The study found that the majority of children were found dependent on the mid-day meal as an alternative for the lunch box and the rest children take their lunch on returning back to their home. Midday meals provide healthy diet to the school age children in school.

The socioeconomic assessment shows that the majority of the children were belonged from upper lower economic class and from SC category among the selected area population. The study found that the childrens' diet 
quality was dependent upon the socioeconomic status of their family which is a major affecting factor. It was also found that the boys were non-vegetarian whereas, majority of the girls were found vegetarian. The dietary assessment of the children found that their diet was adequate with major food groups like cereals and pulses but inadequacy was found for protein group foods like meat, egg and poultry products and also for functional foods like fruits and vegetables. It is suggested to eat healthy energy and protein rich snacks between the major meals in a day to contribute in the daily energy need of the individual.The majority of children were found with low intake of vitamins such as ascorbic acid, retinol and beta carotene due to their low intake of fruits and vegetables. The habit of skipping meals was found common among children. The study found that the majority of children were found irregular to drink milk. The study found that the majority of children were found dependent on the midday meal.

\section{Acknowledgement}

I express my heartfelt gratitude to my major advisor Dr. Pinki Khanna Prof. Dept. of Home science and Hospitality Management PSSCIVE Bhopal (Madhya Pradesh) for her valuable and gifted guidance, keen interest, and constant encouragement. The researchers are thankful to the children who cooperate nicely.

\section{References}

Bora Parul and Kulshreshtha Kalpana (2016), Assessment of nutritional status of school-going children in the age group 7-9 Years. Asian Journal Home Science, volume 11, issue (1): 238-245

Bukhari Hassan Mazher (2013). Anthropometric Measurements and the Effect of Breakfast Sources in School
Achievement, Physical Activity and Dietary Intake for 6-13 Years Old Primary School Children Girls in Makkah City. International Journal of Nutrition and Food Sciences. Vol. 2, No. 6, pp. 272-279.

C., Jegatha (2015), A Comparative Study to Assess the Nutritional Status of Primary School Children (6-10 Years) In Rural and Urban School, International Journal of Innovative Research in Science, Engineering and Technology, Vol. 4, Issue 3:940-944.

Chaudhari Hemakshi E, Kuchake Dr. Vitthal G, Patil Dr. Savita D. 2018 prevalence, awareness and treatment of malnutrition among children's in tribal shirpur. International journal of medical research and pharmaceutical sciences. Volume 5 (issue 4):

Fiorentino M. Landais E, Bastard G, Carriquiry A, Wieringa $\mathrm{F} T$, Berger J. 2016. Nutrient Intake Is Insufficient among Senegalese Urban School Children and Adolescents: Results from Two $24 \mathrm{~h}$ Recalls in State Primary Schools in Dakar. 8 (10).

Gitika Sharma and Lakhawat Sarla, 2016. Nutritional status of school-going children (7-9 years) in a rural area of Bhilwara district (Rajasthan). Asian Journal of Home Science Volume 11, Issue 1: Page No. 220-225

Handa Ruckiha, Ahmad Fatima, 2008. Assessment of Nutritional status of 710 years of school-going children of Allahabad District. Middle-East Journal of Scientific Research. 3(3): 109-115.

Haradanahalli R S, Prashanth R M, Kumari N, Siddhareddy I, Pradeep D P, Surendran J (2019). Personal hygiene practices and related skin diseases among primary school children of the urban poor locality. Int $\mathbf{J}$ Community Med Public Health; vol 6: issue 6:2526-32. 
Jain, Monika; Yadav, Deeksha; Singh, Vandana Chetna; and Chamoli, Ritushri 2018. Nutritional Status and Diet Quality in 7-10 Years Old School Going Children. International Journal for Environmental Rehabilitation and Conservation.

Kalaiselvan Ganapathy, Kumar Annapurna,
Dongre Amol R, V Purushothaman (2012). Assessment of the nutritional status and morbidity related to personal hygiene among the school children's in a rural area of Puducherry. Nat.J.Res.Com. Med, volume 1 issue (2):96-100.

\section{How to cite this article:}

Anoop Kumar and Pinki Khanna. 2021. Nutritional Status of School Going Children (7-9 years) on the Basis of Food Habit in Rural area of Kanpur Dehat District (Uttar Pradesh). Int.J.Curr.Microbiol.App.Sci. 10(06): 566-574. doi: https://doi.org/10.20546/ijcmas.2021.1006.062 